\title{
SOME RESULTS OF MEASUREMENTS AT THE LETEENSUO EXPERIMENTAL STATION RELATING TO THE TEMPERATURES OF AIR AND SOIL AND TO THE HUMIDITY OF AIR IN THE SUMMER OF 1958
}

\author{
YrJö Pessi and Mauri Takala \\ Society of Peat Cultivation, Leteensuo, Finland
}

Received April 8, 1959

The summer of 1957 was characterized by a rainy latter part and by simultaneous air temperature higher than normal. This resulted in considerable losses in all cereal crops in southern and south-western Finland in the form of sprouting in ear. The occurrence of this phenomenon varied depending on the cereal and the variety, but it was also affected by other factors. At the Experimental Station of Leteensuo it was found that no sprouting in ear occurred on cultivated bog areas, whereas its occurrence was considerable on mineral soil. With Apu spring wheat on mineral soil it was so abundant that more than $50 \%$ of the grains showed sprouting in ear. Since such differences were observed between seeded areas showing the same degree of ripening on a cultivated bog area as well as on mineral soil, it was thought that this might be due to several causes one of them perhaps being the different thermal conditions on the two sites concerned.

No temperature observations were available from the summer of 1957 on the basis of which a closer study of the circumstances could have been made. However, such observations have earlier been made by Vesikivi(3). According to his investigations, the mean air temperature during the growing period in a thermometer hut at $1.6 \mathrm{~m}$ height was largely the same over clay soil and bog soil, and the same applied to an observation height of $0.5 \mathrm{~m}$. The minimum temperatures, on the other hand, were $1.3^{\circ} \mathrm{C}$ lower over cultivated bog areas than over mineral soil (3, p. 11).

In Vesikivi's investigations the thermometer sites were covered by grass meadow, which was kept short-cropped. The results are thus not immediately comparable to a case where the plant cover consists of cereal. On the other hand the yalue of his investigations is increased by the fact that they extend over several years; it is also reasonable to assume that similar differences in thermal conditions will occur in grain fields. However, the procedure employed by Vesikivi was 
somewhat different from that used at present in microclimatological research, and for this reason similar temperature measurements were carried out in the summer of 1958 with cereal constituting the plant cover. The work was combined with other investigations aiming at the determination of the differences between the temperatures noted in the meteorological hut of the Experimental Station and the plant cover belt of the cultivated areas. Soil temperature measurements and some phenological observations were furthermore included in this investigation.

The air temperature was measured with the aid of thermometers of three different types. The minimum temperature was measured with alcohol minimum thermometers (R. Fuess), and the observations required for the calculation of the mean air temperature were made with common mercury-in-glass thermometers (R. Fuess) located in meteorological huts. Some observations were further made with the aid of the Assmann aspiration psychrometer (Lambrecht).

All measurements were performed without radiation shields. The thermometers on the cultivated areas were kept constantly at the upper limit level of the plant cover. Series of observations were also taken with the Assmann psychrometer at $10 \mathrm{~cm}$ above the soil surface. Between four and five measurements at both heights were made simultaneously on both sites of measurement. With a view to a minimum disturbance of the air in the vegetation belt, special mounting frames were designed for the psychrometers, by which the height of measurement could be controlled from a distance of about 2.5 metres and the observer had to approach the instrument for the taking of readings only. In addition to mutual comparisons between all thermometers of one kind, the thermometers were also frequently exchanged from one site of measurement to the other during the summer.

The soil temperature was measured with the aid of mercury-in-glass thermometers expressly designed for this purpose and previously used by VESIKIVI (2, p.3) in his investigations on the same bog area. The measuring depths were 5 and $10 \mathrm{~cm}$.

All observations, excepting those with the Assmann psychrometer, were made three times a day, at $8.00,14.00$ and 20.00 hours. The daily mean temperatures have been calculated as a mean of these observations. The minimum thermometers were read at 8.00 hours.

VESIKIVI's method of investigation was somewhat different from that described above. His thermometers at $1.6 \mathrm{~m}$ height were placed in a hut and those at $0.5 \mathrm{~m}$ on top of posts protected from solar radiation. Moreover, he also measured the temperature at soil surface $(3$, p. 9). The essential departure, in the present investigation, from his methods is that the thermometers were unprotected from radiation in our work.

The objects of measurement on the cultivated areas had a mutual distance of about 400 metres. The difference in elevation between the mineral soil and cultivated bog plots was 5 metres. The meteorological observation hut of the experimental station is located in the centre of an open space surrounded by trees, wind break plantations and buildings. The difference in level between this location and the cultivated bog areas was about 5.5 metres.

The results of the investigation have been presented in Tables 1 to 3 . It can be seen, among other things, that the temperature differences between the various 
Table 1. Deviations of the monthly mean temperatures, and the monthly means of the minimum temperatures at the sites of observation from the corresponding means in the meteorological observation hut, degrees Centigrade.

\begin{tabular}{|c|c|c|c|c|c|c|c|c|}
\hline \multirow[t]{3}{*}{ Month } & \multicolumn{4}{|c|}{ Mean temperature } & \multicolumn{4}{|c|}{$\begin{array}{c}\text { Mean of } \\
\text { minimum temperatures }\end{array}$} \\
\hline & \multirow[t]{2}{*}{ 1) } & \multicolumn{3}{|c|}{$\begin{array}{l}\text { Mean from site of } \\
\text { observation minus } \\
\text { mean from hut }\end{array}$} & \multirow[t]{2}{*}{ 1) } & \multicolumn{3}{|c|}{$\begin{array}{l}\text { Mean from site of } \\
\text { observation minus } \\
\text { mean from hut }\end{array}$} \\
\hline & & Fen & $\begin{array}{l}\text { Sph. } \\
\text { bog }\end{array}$ & $\begin{array}{l}\text { Mineral } \\
\text { soil }\end{array}$ & & Fen & $\begin{array}{l}\text { Sph. } \\
\text { bog }\end{array}$ & $\begin{array}{l}\text { Mineral } \\
\text { soil }\end{array}$ \\
\hline VI & 14.9 & 1.1 & 1.5 & 1.5 & 5.9 & -2.5 & -3.0 & -1.5 \\
\hline VII & 16.8 & 0.4 & 0.1 & 0.8 & 9.5 & -2.6 & -3.1 & -2.4 \\
\hline VIII & 15.2 & 0.1 & 0.0 & 0.5 & 7.9 & -1.9 & -2.3 & -1.4 \\
\hline IX & - & - & - & - & 3.9 & -2.3 & -2.6 & -1.2 \\
\hline
\end{tabular}

1) Mean of observations in the meteorological hut.

Table 2. Relative humidity of the air, $\%$, at the upper limit level of the plant cover and $20 \mathrm{~cm}$ above soil surface over cultivated mineral soil, fen and Sphagnum bog at certain times on two cloudless days.

The wind velocity varied between 3 and 4 metres per second during the measurements.

\begin{tabular}{|c|c|c|c|c|c|c|c|c|}
\hline \multirow[t]{2}{*}{ Date } & \multirow[t]{2}{*}{ Time } & \multicolumn{3}{|c|}{$\begin{array}{l}\text { Relative humidity, \%, } \\
\text { at upper limit level } \\
\text { of vegetation }\end{array}$} & \multicolumn{3}{|c|}{$\begin{array}{c}\text { Relative humidity, } \% \text {, } \\
20 \mathrm{~cm} \text { above } \\
\text { soil surface }\end{array}$} & \multirow[t]{2}{*}{$\begin{array}{l}\text { Plant } \\
\text { cover }\end{array}$} \\
\hline & & Fen & $\begin{array}{c}\text { Mineral } \\
\text { soil }\end{array}$ & $\begin{array}{l}\text { Differ- } \\
\text { ence }\end{array}$ & Fen & $\begin{array}{c}\text { Mineral } \\
\text { soil }\end{array}$ & $\begin{array}{c}\text { Differ- } \\
\text { ence }\end{array}$ & \\
\hline 11. VII & 9.54 & 50 & 43 & 7 & 69 & 33 & 36 & Cereal \\
\hline 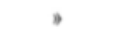 & 10.49 & 45 & 34 & 11 & 53 & 34 & 19 & 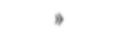 \\
\hline , & 15.39 & 43 & 32 & 11 & 51 & 34 & 17 & , \\
\hline 13. VIII & 13.34 & 49 & 32 & 17 & 67 & 36 & 31 & , \\
\hline , & 15.19 & 45 & 41 & 4 & 69 & 50 & 19 & Potatoes \\
\hline
\end{tabular}

Table 3. Deviations of the monthly mean soil temperatures, at 5 and $10 \mathrm{~cm}$ depth, in cultivated fen and Sphagnum bog from the corresponding mean temperatures in mineral soil, degrees Centigrade.

\begin{tabular}{|c|c|c|c|c|c|c|}
\hline \multirow[t]{3}{*}{ Month } & \multicolumn{3}{|c|}{$\begin{array}{c}\text { Mean soil temperature } \\
\text { at } 5 \mathrm{~cm} \text { depth }\end{array}$} & \multicolumn{3}{|c|}{$\begin{array}{l}\text { Mean soil temperature } \\
\text { at } 10 \mathrm{~cm} \text { depth }\end{array}$} \\
\hline & \multirow[t]{2}{*}{ 1) } & \multicolumn{2}{|c|}{$\begin{array}{l}\text { Mean from site of } \\
\text { observation minus mean } \\
\text { from mineral soil }\end{array}$} & \multirow[t]{2}{*}{ 1) } & \multicolumn{2}{|c|}{$\begin{array}{l}\text { Mean from site of } \\
\text { observation minus mean } \\
\text { from mineral soil }\end{array}$} \\
\hline & & Fen & $\underset{\text { bog }}{\text { Sphagnum }}$ & & Fen & $\underset{\text { bog }}{\text { Sphagnum }}$ \\
\hline VI & 15.4 & -0.5 & -0.7 & 14.3 & -0.9 & -1.3 \\
\hline VII & 17.8 & -0.8 & -1.4 & 16.9 & -0.6 & -1.1 \\
\hline VIII & 14.7 & 0.4 & 0.6 & 14.3 & 0.4 & 0.4 \\
\hline
\end{tabular}

1) Mean temperature in the mineral soil. 
cultivated areas have been largely similar to those established in VESIKIVI's investigations $(3$, p. 11). On the other hand the soil temperature differences between mineral soil and bog have remained smaller than e.g. in the tests carried out by Pessi (1) at Pelsonsuo. In August the soil temperature has even been higher on the bog than in mineral soil. This is probably accountable, in the first place, to the thermal conditions of the summer in question, particularly to the low rainfall in its latter part. Since the rainfall in August was only $47 \mathrm{~mm}$, it is likely that on the bog the thermal energy required for evaporation has also been less than usual.

Conclusions

The mean temperature in June was about $1.5^{\circ} \mathrm{C}$ lower in the meteorological hut of the experimental station, at $2 \mathrm{~m}$ height, than at the upper limit level of the vegetation belt on the cultivated areas. The differences became less at later times and in August they were nearly nonexistent.

The monthly mean temperatures at the upper limit level of the plant cover were practically the same on mineral soil and on the cultivated bog.

The monthly mean of the minimum temperatures on the Sphagnum bog was about $0.5^{\circ} \mathrm{C}$ lower than on the fen, the latter being about $0.5-1.0^{\circ} \mathrm{C}$ lower than on cultivated mineral soil.

The relative humidity of the air in the vegetation belt, on cloudless days, was considerably higher on the cultivated bog areas than on mineral soil.

The soil temperature differences remained fairly small in the year of investigation. During June and July the temperature was higher in the mineral soil than in the fen and Sphagnum bog but in August it was lower.

\section{REFERENCES}

(1) Pessi, Y, 1957. On the thermal conditions in mineral and peat soil at Pelsonsuo in $1955-1956$. Selostus: Kivennäismaan ja turvemaan lämpöoloista Pelsonsuolla vuosina 1955-1956. Valt. maatal.koetoim. julk. 159: 1-40.

(2) Vesı́ıvı, A, 1933. Suomaan lämpötilamittausten tuloksia. Referat: Ergebnisse von Temperaturbeobachtungen im Moorboden. Suom. Suovilj.yhd. tiet. julk. 15: 1-19.

(3). _— 1941. Savimaalla ja viljellyllä suomaalla sekä ojitetulla ja ojittamattomalla rahkarämeellä suoritettujen ilman lämpötilahavaintojen tuloksia. Referat: Ergebnisse von Lufttemperaturbeobachtungen auf Tonboden und bebautem Moorboden sowie auf entwässertem und unentwässertem Sphagnum fuscum-Reisermoor. Ibid. 18: 1-53. 


\title{
ERÄITÄ ILMAN JA MAAN LÄMPÖTILAA SEKÄ ILMAN KOSTEUTTA KOSKEVIA MITTAUS- TULOKSIA LETEENSUON KOEASEMALLA KESÄLLÄ 1958
}

\author{
YrJö Pessi ja Mauri Takala
}

\section{Suoviljelysyhdistys, Leteensuon koeasema}

Tutkimuksessa selostetaan mittaustuloksia, joita on suoritettu koeaseman säähavaintokojussa sekä kivennäismaa- että muta- ja rahkasuoviljelyksillä. Tuloksista voidaan tehdä seuraavia päätelmiä:

Kesäkuun keskilämpötila on ollut koeaseman säähavaintokojussa 2 metrin korkeudella noin $1.5^{\circ} \mathrm{C}$ alhaisempi kuin kasvillisuuskerroksen ylärajassa viljelyksillä. Myöhemmin erot ovat pienentyneet ja ovat olleet elokuussa jo lähes olemattomat.

Kuukauden keskilämpötilat ovat olleet kivennäismaalla ja suoviljelyksillä kasvillisuuskerroksen ylärajassa jokseenkin samat. Minimilämpötilojen kuukauden keskiarvo on ollut rahkasuolla noin $0.5^{\circ} \mathrm{C}$ alhaisempi kuin mutasuolla ja mutasuolla noin $0.5-1.0^{\circ} \mathrm{C}$ alhaisempi kuin kivennäismaaviljelyksellä.

Kasvillisuuskerroksen ilman suhteellinen kosteus on selkeinä vuorokausina ollut suoviljelyksellä huomattavasti suurempi kuin kivennäismaaviljelyksellä.

Maan lämpötilaerot ovat tutkimusvuonna jäăneet melko vähäisiksi eri maalajien välillä. Kesäja heinäkuussa kivennäismaan lämpötila on ollut korkeampi kuin muta- ja rahkasuon, mutta elokuussa alhaisempi. 